\title{
TIME AND MEANING. ALFRED SCHUTZ'S CONCEPT OF INTERSUBJECTIVITY AND ITS COGNITIVE COROLLARIES
}

\begin{abstract}
Why Alfred Schutz's legacy influenced so much social theory, remaining much less known in the world of philosophy, and phenomenology in particular? The paper tries to show its importance for the phenomenological tradition, pointing to its relevance for such philosopical problems as understanding of the phenomenological reduction, self-evidence, the reproach of psychologism, constitution of meanings and realism vs. idealism in phenomenology. Highlighting Husserl's high esteem for Schutz, it departs from the historical background of Schutz's reflection (the Austrian school of law and economy, neo-kantianism of the Marburg and the Baden school and its influence on Max Weber, Husserl's dispute with psychologism) in order to show, on the example of "The Phenomenology of the Social World", how Schutz finds his way from the solipsistic trap, finding a solution of the self-evidence problem by means of providing a description of the pre-reflexive and of the reflexive side of the time structure, inherent in the process of the social constitution of meaning.

The text proceeds by delineating historical background of Schutz's reflection: first of the inspiration of his philosophy by legal and economic theories, then of his engagement in the discussion on grounding the humanities, of Max Weber's position in this discussion, constituting a point of departure for Schutz, and, finally, of Schutz's relation to the basic issues of phenomenology, comprised in the question of psychologism. After this introduction Schutz's project turns out to be a reconstruction of processual self-evidence, realized in co-existence of various streams of consciousness, in a way congenial to Heidegger's "Time and Being".
\end{abstract}

Keywords: phenomenology, neo-kantianism, social theory, Alfred Schutz, Edmund Husserl, Max Weber.

The very fact that Alfred Schutz's sociophenomenology, a peculiar brand of phenomenological reflection exploring the motive of intersubjectivity, acquired a remarkable status in the world of social theory and inquiries, passing until now almost without notice among philosophers - in particular in various phenomenological milieus - is a remarquable phenomenon in and of itself, deserving further consideration. Its utility and attractivity for sociology is the more worth our attention that it is in fact an attempt to overcome the allegedly subjective or solipsistic trait of modern philosophizing based on consciousness (often called "Cartesian"), which at the beginning of the XX century, especially in German speaking philosophical circles strongly influenced by neo-kantianism, took form of the basic question concerning the subject's cognitive access to the world. Schutz's sociophenomenology, therefore, is an attempt to find an answer to this question by developing a very specific kind

${ }^{1}$ Dr Marek Chojnacki, e-mail: mchojnacki@go2.pl 
of reflection on social action (Handeln), conceived - in a theoretical project that is now being labelled as "protosociology"2 - as a harmonization of two (or more) streams of consciousness with the purpose to deliberately act upon the world. The present paper is an attempt to analyze Schutz's philosophical project from this particular point of view.

\section{HISTORICAL BACKGROUND OF SCHUTZ'S REFLECTION: PHENOMENOLOGY'S MAIN PROBLEM}

George Walsh in his introduction to the English edition of Alfred Schutz's fundamental oeuvre from his early German period, The Phenomenology of the Social World ${ }^{3}$, stresses the importance of Schutz to phenomenology, emphasized by Edmund Husserl himself. Alfred Schutz, having acquainted himself with the neo-kantian philosophy, as well as with legal and economic doctrines prevailing at the time of his studies at the university of Vienna in the 1920s and 1930s - in particular with Hans Kelsen's philosophy of law and with the economical doctrine of Ludwig von Mises, "discovered the relevance of the phenomenology of the consciousness of inner time of Edmund Husserl"4 and got in touch with the founder of phenomenology, who wanted to make him his assistant - a plan that could not be put into practice because of historical circumstances, as Schutz had to flee the Nazi regime, emigrating first to Paris, and then, in 1939, to the United States. Walsh quotes one of Husserl's letters to Schutz just before their meeting, in which Husserl expresses his high esteem for Schutz's phenomenological thinking and understanding for his own basic theoretical problems:

"I am anxious to meet such a serious and thorough phenomenologist, one of the few who have penetrated to the core of the meaning of my life's work, access to which is unfortunately so difficult, and who promises to continue it as a representative of the genuine philosophia perennis which alone can be the future of philosophy"5.

In the light of such a resolute and univocal statement, it is maybe not unjustified to treat Alfred Schutz not as one of the many who tried their chances in the vast field of phenomenology, with its numerous streams, currents and schools, haunted, as they all are, by interminable, more or less grounded doubts concerning their solipsism or idealism ${ }^{6}$, but as

2 Cf. Luigi Muzzetto, „Time and Meaning in Alfred Schütz”, Time and Society 15 (2006), p. 6; J. Dreher, "Einleitung”, in: T. Luckmann, Lebenswelt, Identität und Gesellschaft, Universitätsverlag Konstanz, Konstanz 2007, p. 8; T. Luckmann, „Geschichtlichkeit der Lebenswelt?“, Filozofski Vestnik 2 (1991), p. 24-25.

3 A. Schutz, The Phenomenology of Social World, transl. and ed. by G. Walsh and F. Lehnert, Northwestern University Press, Evanston, Ill. 1972 [1967]; original edition: Alfred Schütz, Der sinnhafte Aufbau der sozialen Welt. Eine Einleitung in die verstehende Soziologie, Springer Verlag, Wien 1960 [1932].

${ }^{4}$ M. Barber, „Alfred Schutz”, in: E.N. Zalta, U. Nodelman, C. Allen, R.L. Anderson (ed.), Stanford Encyclopedia of Philosophy, Stanford University, Stanford, CA 2016, https://plato.stanford. edu/entries/schutz/

5 G. Walsh, „Introduction”, in: A. Schutz, The Phenomenology of the Social World, op.cit., p. XVIII

6 The list of authors notoriously accusing Schutz of idealistic transcendentalism, egology and solipsism, from which he allegedly tries to distance himself or to cut himself off, is very long, from Ilja Srubar's Kosmion (I. Srubar, Kosmion. Die Genese der pragmatischen Lebensweltstheorie von Alfred Schütz und ihr anthropologischer Hintergrund, Suhrkamp, Frankfurt am Main 1988, the chapter „Schütz’s Ablösung von der transzendentalen Phänomenologie“, p. 256-270) to T. Blin’s 
a thinker of paramount importance, whose intuitions may be the key to phenomenology as such.

\section{First incentives of Schutz's sociophenomenology: the Austrian law and economy school}

Alfred Schutz's thinking was marked from the beginning by a particular theoretical angle or point of departure. Already the economical school of Ludwig von Mises, who deeply influenced Schutz before he took interest in phenomenology - especially by his polemics with Max Weber concerning the understaning of the postulate of a value-free social theory ${ }^{7}$ - stressed the utmost importance of individual choices of social actors, endowed with ability of motivated, purposeful actions, for the global and universal phenomenon of economic exchange. According to this vision, participants of economic exchange are not hedonistic automata, interested in maximizing abstractly defined pleasure and passively receiving economic offer, but rather active consumers, "aware of their subjective wants and the objective conditions for satisfying those wants" and attributing "to physical things particular degrees of importance" 8 . So the problem of a "sole" subject, unsubjected to any prior generality, but rather creating generalities - e.g. those creating the complex web of economic life - together with other "sole" individuals by means of commonly lived motives, purposes and actions, has been approached by Schutz already before he engaged in stricly philosphical reflection. Hence comes his fundamental intuition: to understand a complex, universal system (for instance an economic system), we have first to decipher actions and motives of individual actor ${ }^{9}$.

more recent „requem for phenomenology“ (T. Blin, Requiem pour une phénoménologie. Sur Alfred Schütz, Merleau-Ponty et quelques autres, Editions du Félin, Paris 2010). It is not the intention of the present paper to enumerate them. This attitude is very recently criticized as a misunderstanding e. g. by Salice and Schmid, who in this context critically discuss the claim, "almost routinely" raised "particularly in the second half of the twentieth century", that "phenomenological analysis of intentionality and consciousness commits to a basically solipsistic position" (A. Salice, H.B. Schmid, "Social Reality - The Phenomenological Approach", in: A. Salice, H.B. Schmid (ed.), The Phenomenological Approach to Social Reality. History, Concepts, Problems, Springer, New York-Berlin-Heidelberg 2016, p. 1-16. 1-2.

7 Cf. G. Walsh, „Introduction”, op. cit., p. XVIII

${ }^{8}$ M. Barber, "If only to be heard: value-freedom and ethics in Alfred Schutz's economic and political writings", in: M. Endress, G. Psathas, H. Nasu (eds.), Explorations of the Life-World. Continuing Dialogues with Alfred Schutz, Springer, Dordrecht 2005, p. 176.

9 T. Blin, Requiem pour une phénoménologie, op. cit., p. 68; N. Marquis, "Blin Thierry, Requiem pour une phénoménologie. Sur A. Schütz, Merleau-Ponty et quelques autres", Recherches sociologiques et anthropologiques, 41-2 (2010) 142-145. "Blin propose de revenir sur les emprunts théoriques de Schütz (parmi lesquelles Husserl, Bergson, James, Von Mises etc.), en commencant par un aspect souvent oublié de son parcours intellectuel: ses accointances avec l'École autrichienne d'économie (Von Mises, Bohm-Bawerk, Von Hayek etc.). Schütz en retiendra une idée fondamentale pour sa sociologie phénoménologique: pour comprendre un système (par exemple économique), c'est au déchiffrement des actions et des motifs individuels qu'il faut s'atteler.' Ibidem, p. 143. 


\section{Further philosophical inspiration: neo-kantianism of the Southwest school}

Another important source of inspiration, that had influenced Schutz before his engagement in phenomenological reflection, is the entanglemet of Schutz's thinking in neo-kantianism, strictly bound to his project of completing the Weberian notion of meaningful social action. Both the milieu of the Austrian school of law and economics (Schutz's first academic context), the Austrian school of Marx interpreters (the so-called Austromarxism) ${ }^{10}$, as well as Max Weber's reflection (in particular through Georg Simmel) were profoundly influenced by Kant and neo-kantianism ${ }^{11}$, in particular in the form of discussions of these times concerning the scientific status of the natural and the humanistic sciences (Naturwissenschaften and Geisteswissenschaften), being a variation of the perennial problem of our cognitive access to the world. The status of sociology - the science for which Schutz decided to find a theoretical grounding - was particularily fragile after its founder Auguste Comte, whose positivism urged him to found sociology on the model of physics, with its general unchanging laws concerning observable facts, and to perceive human cognitive activity as a way of transforming human brain into the exact mirror of objective, immutable external order ${ }^{12}$. With this position - to the ear of a Kantian sounding very much like metaphysics, for suggesting that our mind can faithfully reflect the social world "as it is", just as it reflects the external order in physics, chemistry or biology - sociology after Comte had little chances to develop a critical reflection on its own field of cognition ${ }^{13}$. Hence the significance of debates led in the German speaking circles at the end of the 19 . and at the beginning of the 20. century, especially those influenced by two main representatives of the Baden or Southwest school of neo-kantianism, Wilhelm Windelband and $\mathrm{He}$ inrich Rickert, trying to save the cognitive field of humanities (and sociology in particular) from ruthless charges of a more strict branch of neo-Kantians (from the so-called Marburg school), postulating that only disciplines discovering universal laws and invariable structures, obeying logical or mathematical laws, can be seen as science. The Badenians tried to delineate sociology's own special field by pointing to the domain of values, conceived as some kind of entities of spiritual, nonempirical order, that can nonetheless be refererred to and represented by empirical data gathered, as it is the case in social sciences, not by means

${ }^{10}$ Cf. M. Endress, ,Einleitung der Herausgeber“, in: Alfred Schutz, Der sinnhafte Aufbau der sozialen Welt, UVK, Konstanz 2004, p. 15.

${ }^{11}$ H.J. Helle, Theorie der symbolischen Interaktion. Ein Beitrag zum verstehenden Ansatz in Soziologie und Sozialpsychologie, Westdeutscher Verlag, Wiesbaden 2001, the chapter „Zwischen Positivismus und Neukantianismus“, p. 11-14; E.K. Scheuch, „Vorwort“, in: H.J. Helle, Theorie der symbolischen Interaktion, op. cit., p. 3; T. Nenon, „Max Weber“, in: L. Embree et al. (eds.), Encyclopedia of Phenomenology, Kluwer, Dordrecht-Boston-London 1997, p. 729-732; R.A. Gareman, The dual vision. Alfred Schütz and the myth of phenomenological social science, Routledge, London-New York 2014 [1977], chapter "Max Weber's methodology in its historical context", p. 5-15; J.I. (Hans) Bakker, “The Life World, Grief and Individual Uniqueness: Social 'Definition' in Dilthey, Windelband, Rickert, Weber, Simmel and Schutz, Sociololische Gids 42-3 (1995), p. 187-212.

12 „Alors on reconnaît directement que le plus difficile et le plus important de notre existence intelectuelle consiste à transformer le cerveau humain en un miroir exact de l'ordre exterieur." Auguste Comte, Système de politique positive. Tome deuxième contenant la statique sociale ou le traité abstrait de l'ordre humain, Otto Zeller, Osnabrück 1967 [1852], p. 382; quoted after: H.J. Helle, Theorie der symbolischen Interaktion, op. cit., p. 12.

${ }^{13}$ On Comte as a „metaphysician” from the neo-kantian perspective see H.J. Helle, op. cit., p. 11-12. 
of generalizing (nomothetic) methods, but by means of individualizing (idiographic) sample collecting. But in this context values - objects having a week cognitive and ontological status, supposed not to "be", but to "oblige" or "have significance" (German: Geltung) ${ }^{14}$, according to the famous formula of Herman Lotze, repeated by both the Marburgians and the Badenians - appear to be a paradoxical and unclear concept, and therefore an insufficient ground for justifying sociology's scientific character. As Goreman writes, "Windelband and Rickert have failed to explain how we can scientifically explain aspects of cultural behavior apart from either the metaphysical assumption of Dilthey [postulating an unwarranted, direct link between analized values and some objective, spiritual entities] or the positivists' demand for criteria of objectivity based on empirically confirmed regularities of nature. Their attempts to avoid both metaphysics and empirically verified causal explanation has left them with nothing at all"15.

\section{Max Weber's reaction to the Southwest school and Schutz's point of departure}

As the representatives of the neo-kantian Baden school, with their stress put on the methodological autonomy of humanities and the difference between humanities and the natural sciences, did not manage to adequately justify sociology's claim to scientific validity, the more interesting and promising, especially at the time Alfred Schutz began his career, appeared the solution given to this problem by Max Weber. Weber accepted the logical separation of natural and cultural sciences proposed by Windelband and Rickert, but rejected their view that these two kinds of sciences use radicaly different methods. He contended that both natural and social sciences use both types of methods (i. e. nomothetic or generalizing, and ideographic or individualizing). According to him, both natural and social sciences search for general, universal explanations and occasionally study unique aspects of particular phenomena ${ }^{16}$. This view, rather paradoxical if we take into account the specific efficiency and evidence, with which natural sciences find and prove validity of their general laws, and the notoriously particular, nonuniversal character of descriptions in historical and social sciences, was nonetheless an important step forward towards the explication of scientificity of the latter. In a certain sense, Weber's conception left this particular domain of philosophy of science with more questions than answers, urging - more or less explicitly the question about the nature of the passage from idiographic sampling to nomothetic posing of general rules, structures and laws and about the more complex relations between both kinds of cognitive procedures.

In his description of Alfred Schutz's way to his unique cognitive standpoint, expressed paradigmatically in his early work Der sinnhafte Aufbau der sozialen Welt (1932), Walsh makes clear why and how Weber sought a way out from the ambiguous and opaque

\footnotetext{
14 J. Krasicki, „Russian Values and America”, in: M.C. Flamm, J. Lachs, K.P. Skowroński (ed.), American and European Values. Contemporary Philosophical Perspectives, Cambridge Scholars Publishing, Newcastle 2008, p. 26; G. Rose, Hegel: Contra sociology, The Athlone Press, London 1995 , p. 12. Rose's point of view is interesting for the interpretation of the sociological paradigm, e.g. for her thesis that "the transcendental [i. e. kantian] structure of Durkheim's and of Weber's thought has been persistently overlooked"(p. 1).

${ }_{15}$ R.A. Goreman, The dual vision, op. cit., p. 9.

16 Ibidem, p. 9-10.
} 
language of values, inherited from the world of neo-kantian concepts. ${ }^{17}$ Concerning neo-kantianism, he stresses two traits of the Southwest school, important for understanding of Weber's and Schutz's positions: its strong accent put on subjectivity and the activity of the mind in the process of producing knowledge, related to the priority of values (a reason for which the Badenians were sometimes called neo-Fichteans) and the accent on the processual, actual side of social contents, leading to a certain opposition of actuality and value. So, "Rickert's influence upon Weber lay chiefly in the notion of actuality as an unorganized manifold which is then approached from the standpoint of certain interests or values and so organized into a conceptual system. However, Weber insisted, as Schutz makes clear, that in quite another sense science is perfectly objective and value-free (wertfrei). "It is one thing to ask questions in terms of a value or interest. It is quite another thing to answer them in such terms"18. If, therefore, values in Weber's theoretical proposal lose their explicative power in favor of a kind of scientific objectivity based on "actuality as an unorganized manifold", it seems perfectly logical that this "manifold" must get rid of its allegedly "unorganized" character, becoming a set of social, subjective practices and actions endowed processual as they are - in some capacity of order, analizable and understandable scientifically. This is exactly the point Schutz will make, making sense of Weber's notion of meaningfulness of social actions, and making explicitly reference to the Southwest school ${ }^{19}$.

\section{Husserl's discussion with the Marburg school on psychologism and Schutz's main phenomenological problem}

Before, however, we consider Schutz's project of analyzing phenomena of social order, viewed as fundamentally subjective meaningful actions, in their paradoxically transcendental and/or mundane character, and thus revealing the deeply cognitive insight of Schutz's social thought, we should first turn our attention to the fact that - as we have noticed initially - Alfred Schutz, creating his theory of social action, was first of all a phenomenologist: not only a social thinker inspired by phenomenology, but an original and pungent phenomenologist on his own, considered by Edmund Husserl to be one of his most promising disciples. If then his "protosociology" was to give an answer to the basic phenomenological questions, then it has to deal with the fundamental issue permeating Husserl's project in its totality the problem of self-justification of human cognition by means of the givenness of what "shows" itself in the perceptual, intuitive web of conscious acts and their intentional correlates (Anschauung) $)^{20}$. In other words, it has to deal - at least implicitly - with the problem of the so-called self-evidence.

${ }^{17}$ G. Walsh, „Introduction”, in: A. Schutz, The Phenomenology of the Social World, op. cit., p. XIX-XXVI.

18 Ibidem, p. XX.

${ }^{19}$ Cf. A. Schutz, The Phenomenology of the Social World, op. cit., in particular the paragraph "Max Weber's Concept of Meaningful Action", p. 15-20, and the paragraph "Transition to the Analysis of the Costituting Process. Clarification of the Concept of "Attaching Meaning to an Act" (p. 38-44), where Schutz explicitly mentions the Southwest German school as inspiration for Weber's understanding of the intended meaning of social action (p. 43).

${ }^{20}$ A. Schutz in The Phenomenology of the Social World does not mention explicitly the representatives of the Marburg school; he does mention, however, at the very beginning of The Phenomenology of the Social World, the divergence between Rudolf Carnap and Edmund Husserl as to the possibility of knowing the other's inner states, i.e., concerning the very possibility of meaningful 
Husser's question of self-evidence, posed the most explicitly in his "Logical Investigations" (Logsche Untersuchungen (1900) - LU), reveals the deeply problematic character of any justification of what we may call adequacy - the upright character of our cognitive references to the world. Profoundly intertwined as it is with the neokantian context, it points to the real purpose of critical philosophy after Kant - aware of the impossibility of any direct conceptual grasping of "things as they are" (Ding and sich), and tending nonetheless to cognitively find a way to them, thanks to some stable "conditions of possibility" of knowledge, considered to be its a priori. If our perceptions or judgements are to be "adequate" in this sense (let us use the word "adequate" without reference to its complex mortgage and to the fact Husserl uses this word in a different context) on the ground of their intentional structure, as learned Husserl's master Brentano, they somehow have to be self-evident inasmuch as they reach the outer world, irreductible to the subject's phantasms or conceptual schemes. That is why Husserl - just as the neo-Kantians of his day, confronted with Brentano's notion of intentionality - with his postulate of getting zurück zu den Sachen selbst, is wrestling with the reproach of psychologism, trying (in vain inasmuch as he is still not able to go beyond perceptions, concepts and judgments) to show he can sufficiently describe a genuine act of cognition, having at his disposal something more than a sheer feeling that what one "sees" is right. This apparently futile effort leads to contradictions on the one hand, remarks Husserl, "if we were not allowed to trust self-evidence any more, how could we make, and reasonably defend, any assertions at all?"21, and, on the other hand, he must admit that "one might then ask what gives such a special feeling authority, how it manages to guarantee the truth of our judgement, 'impress the stamp of truth' on it, 'proclaim its truth', or whatever other metaphor one cares to use",22. One may contend that, inasmuch as we see Husserl's oeuvre as a continuity and a coherent whole ${ }^{23}$, his later writings were an attempt to describe - by means of such notions as the transcendental subject, lifeworld and the like - a kind of "self-evidence" irreductible to a psychological "feeling".

This mysterious gnosiological character of self-evidence - being, as we said, at the same time a psychological feeling and something we cannot treat as such, if its justifying capacity is to be maintained and defended - takes on an almost mythological shape, as, according to Husserl, "to every truth-as-such correspond, ideally or conceptually, a possible judgement of some possible (human or inhuman) intellect in which that truth was experienced as self-

synchronizing of streams of consciousness (p. 21-22). Given the influence of the Marburgians on the Vienna Circle (cf. e. g. T. Uebel, "Vienna Circle", in: The Stanford Encyclopedia of Philosophy (2016), https://plato.stanford.edu/entries/vienna-circle/), the connection of this passage to our point here becomes visible.

${ }^{21}$ E. Husserl, Logical investigations, transl. J.N. Findlay, Routledge, London-New York 2008 [1900], $\S 40$, p. 90-100; quoted after: M. Kusch, Psychologism. A Case Study in the Sociology of Philosophical Knowledge, Routledge, London-New York 1995, p. 82.

22 E. Husserl, Logical investigations, op. cit., § 51, p. 120; cf. M. Kusch, op. cit., p. 82

${ }^{23}$ If we do not agree, e.g., with Kevin Mulligan's and Barry Smith's brilliant classical review of Logical investigations (Kevin Mulligan, Barry Smith, "Husserl's Logical Investigations", Grazer Philosophische Studien 27(1986), p. 199-207), stating that it was "Husserl's one true masterpiece" and that his later writings, tending to be "unclear and to suffer from an excess of grandiose terminology" (ibidem, p. 199) only contributed to the lack of proper reception of his thought. It seems that adherents of the opposite, hermeneutical and hence "non-exact" and non-analytical lecture of Husserl, share the same tendency to oppose two different philosophical projects in Husserl's writings, inclining towards the opposite opinion. 
evident". ${ }^{24}$ It is no wonder, therefore, that the famous reproach of psychologism went in both directions; Husserl and the neo-Kantians of his time (especially the representatives of the Marburg school, focused on the very core of Kant's epistemological aporia) mutually accused each other of the psychologistic fallacy, claiming at the same time that the opponent borrows their own arguments against $\mathrm{it}^{25}$. As Wilhelm Wundt, one of the founders of modern psychology and one of the participants of the mentioned discussion, has put it in his critique of Husserl's alleged inability to define self-evidence, "even stranger than the failure of psychologism is the fact that logicism [i.e., Natorp's, Brentano's and Husserl's position] fares no better. The latter fares no better despite its empathic appeal to the self-evidence of logical laws. This is because logicism's appeal [to the self-evidence of logical laws] moves in a continuous circle: it declares logical laws self-evident, but then again it bases selfevidence upon the validity of logical laws. In order to escape this circle, logicism can do no better than explain that self-evidence is an ultimate fact which cannot be further defined. And since a fact can only be regarded as existing if it is somehow given within a perception [Anschauung, intuition], it is understandable that logicism treats immediate perception and indefinability as equivalent modes of justification (...). However, since every immediate perception is a psychological process, the appeal to immediate perception amounts to a relapse into psychologism"26.

Figuratively speaking, everybody at the time Logical Investigations have been issued and reviewed felt that something has to be done with the conundrum of psychologism, and nobody found an adequate language or concepts to solve the problem. From this point of view, Husserl's further inquiries, however they may be perceived by his critics as "too esotheric"27, "unclear" or "suffering from an excess of grandiose terminology"28, may be seen as an attempt to ground our cognitive openness to the world in the activity of the subject(s) of intentional acts, the primordial Anschauung (understood at the same time as perception and intuition), in such a way as to make visible the non-psychological, purely gnosiological character of something that is initially, intuitively perceived as the experience (Erlebnis) of self-evidence.

Here comes the sociophenomenological project of Alfred Schutz, that, if considered from this point of view, may be interpreted as an important answer to this basic phenomenological question, being in itself a variation of the even more fundamental problem of modern philosophy after Descartes, dealing with the paradox of our cognitive access to the world "out there". With this possible interpretation in view, we will now try to revise some common and basic philosophical opinions concerning Alfred Schutz's protosociology. From our considerations hitherto it may be concluded that to understand Schutz's phenomenological project we need to reflect on it in the context of epistemological discussions of his time, especially in the context of the neo-kantian tradition, and that in the neo-kantian

${ }^{24}$ M. Kusch, op. cit., p. 82; cf. E. Husserl, Logical investigations, op. cit., § 50, p. 116-118.

${ }^{25}$ In this kind of a deeply confused dialogue were engaged, apart from such prominent figures as E. Husserl and P. Natorp, such philosophers as Busse, Heidegger, Heim, Jerusalem, Moog, Palagyi, Schuppe, Wundt, Cornelius, Erdmann, Höffler, Lipps, Mach, Meinong, Sigwart and Rickert; cf. M. Kusch, op. cit., p. 82-89.

26 W. Wundt, Kleine Schriften, vol. 1, Wilhelm Engelmann Verlag, Leipzig 1910, p. 623-625; quoted after: M. Kusch, op. cit., p. 82-83.

${ }^{27}$ M. Kusch, op. cit., p. 88.

${ }^{28}$ K. Mulligan, B. Smith, "Husserl's Logical Investigations", op. cit., p. 199. 
world the strictly epistemological attitude of the representatives of the Marburg school, such as Paul Natorp and Herman Cohen, may be even more relevant to this topic of consideration that discussions of the adherents of the Southwest school, focused on the methodological difference between the natural sciences and humanities, although the latter are closer to the subject matter of protosociology, by means of which Schutz expressed his answer to phenomenology's fundamental question. The mysterious fact that Schutz's considerations, being fundamentally a philosophical and ontological project, attained such a great signifficance in the social sciences, while passing almost without notice in philosophical milieus, remains an interesting issue in and of itself.

Presenting the fundamental problem of phenomenology, as we have presented it, pointing to the three sources influencing Schutz's thought (individualizing theories of economy and law, the discussion between Weber and the Badenians concerning methodology of social sciences, and the discussion of self-evidence between Husserl and the Marburgians) in the reverse order, we may now speak of an individual, allegedly "sole" subject of conscious acts, realizing social and cognitive order in Rickert's and Weber's actuality, passing from individualizing sampling to general laws. If this way of explicating the self-evidence of knowledge is to defend itself against the reproach of solipsism or idealism, it has, in the first place, to present itself as an intersubjective process, passing from the allegedly solitary awareness, through harmonization of various streams of consciousness, to the "closer" We-perspective, and then to the more general, idealized and typified They-perspective, capable of yelding general laws, patterns and schemes, in the continuous course of attributing (social) "actions" their "meanings". This is exactly what Schutz does, offering at the beginning of his theoretical journey, in his fundamental and seminal work "The Phenomenology of Social World" (Der sinnhafte Aufbau der sozialen Welt, 1932) a comprehensive reconstruction of the (sole and social) subject's relation to the world, comparable only to Martin Heidegger's Being and Time ${ }^{29}$. This is, therefore, how the sociological perspective turns out to be a solution of the problem of apparent solipsism in the philosophy of consciousness.

Secondly, in order to defend itself against the accusation of solipsism, this way of explicating self-evidence of knowledge has to present itself as an intersubjective process rather than series of separate acts with distinct justifications, though it is clear that the word "process" is in this context insufficiently explanatory and clear. Whatever the self-evidence discussed by Husserl and the Marburgians may be, it would have to be understood rather as some kind of process or cognitive procedure than as an attrubute of separate cognitive acts, be it prepredicative or predicative. But we will not be able to develop this aspect in the present paper.

Let us now see how Schutz, whose sociophenomenological theorizing can be hardly viewed as transcendental solipsism, develops his description of the intersubjective process of establishing/realizing self-evidence, in which harmonization of multiple streams of

\footnotetext{
${ }^{29}$ If some authors - as does P.K. Aspers, "The Second Road to Phenomenological Sociology", Society 47-3 (2010), p. 214-219 - ask if it were not better if modern sociology, looking for a theoretical ground of the social practices, turned rather to Heidegger's existential ontology than to the phenomenology of Alfred Schutz, stating that "had social science phenomenologists also studied Heidegger, we could be better off" (ibidem, p. 217), it is not unreasonable to ask if Schutz and phenomenology have been properly understood, if we still see him as asolipsistic thinker.
} 
consciousness plays a preponderant role. The quest for meaning attributed to social actions becomes thus the quest for the flow of time.

\section{THE WAY OUT OF THE SOLIPSISIC TRAP: SCHUTZ'S PHILOSOPHY OF (INTER) SUBJECTIVE TIME}

\section{Schutz's "The Phenomenology of the Social World": the basic line of thought}

The basic structure of "The Phenomenology of the Social World" ${ }^{30}$ reveals the fundamental structure of the social subject's being in the world. Schutz proceeds from formulating the postulate of theoretical grounding of Max Weber's concept of meaningful action (part 1., p. 3-44) and stating the need of "clarification of Max Weber's basic concept of interpretive sociology", of such concepts of his theory as "direct understanding and motivational understanding", "subjective and objective meaning" and "meaningful action and meaningful behavior" (p. 13), to the constitution of meaningful lived experience in the individual stream of consciousness (part 2., p. 45-96), stressing that he "lean[s] heavily on Bergson's concept of duration and even more on Husserl's analysis of the constitution of subjective experience" (p. 13). The notion of constitution - a key concept for understanding Husserl's project of phenomenology - may be treated here as equivalent of self-evidence as process or cognitive procedure, to which we have referred formerly.

This reconstruction of the constitution of meaningful experience is further realized by Schutz as a "theory of intersubjective understanding" (part 3., p. 97-138), enabling him to clarify the passage from the subjective to the objective meaning, from the direct harmonizing of two individual streams of experience to the complex and standarized world of signs and sign systems. This passage is particularly well visible in his description of "the structure of the social world" (part 4., p. 139-214), conceived as the last of the four main parts of the book. Here we see clearly, already in the very structure of chapters, the transit from the face-to-face intersubjectivity and the we-relationship (p. 163-175) to the complex, anonym social structure, the "world of contemporaries" with its they-relationship, ideal types and ideal-typical interpretive schemes, constituting a subject of indirect social observation (p. 176-206). So, as we see, this theoretical reconstruction of the social being-in-the-world (to borrow a phrase from Martin Heidegger) proves to be the reconstruction of processual self-evidence, conceived as constitution of social meaning and passing from idiosyncratic direct intersubjective experience to complex, anonym, objective social and cognitive structures. Hence - indirectly and implicitly, because Schutz does not postulate such an outcome of his analysis - the basic Husserlian problem of self-evidence/constitution seems to be clarified.

\section{Schutz's fundamental intuition: the pre-reflexive and the reflexive side of the time} structure

If we are to grasp properly this basic dimension of Schutz's reflection - to understand, how in his theory the meaning constitutes itself, or becomes self-evident, not only in some kind of an insulated solitary consciousness, but in our common, "real", social world, we have to conceive properly the passing from the subjective to the objective meaning, inter-

\footnotetext{
${ }^{30}$ See footnote 2.
} 
twined with the temporal structure of social action itself and of its thematic, conceptual side. One of the criticisms of Schutz of the comprehensive sociology of Weber is that it did not pay sufficient attention to time in the examination of meaning. The Austrian sociologist reworks therefore the theses on time of Bergson and Husserl (mainly from his lectures on the consciousness of internal time) in a synthesis that helps us to understand processes related to the constitution of subjectivity and the intersubjectivity in the world of everyday life. ${ }^{31}$ Because it is in the specific time-structure of our (inter)subjective actions and acts that the meaning reaches its constitution, the proper description of this temporal constitution of meaning is crucial. This justifies Schutz's pregnant phrase from "The Phenomenology of the social world", that becomes increasingly present and commented in the recent reception of his sociophenomenology: "the problem of meaning is a time problem."32 "Sinnproblem ist ein Zeitproblem"33.

If we take this phrase seriously, we have good chances to go beyond the understanding of Schutz focused on his (or Husserl's) allegedly idealistic transcendental ego constructing its meanings, and accusing him of the solipsistic conception of the world ${ }^{34}$. Schutz reconstructs the world of social actions, shared by the subjects with the others in the common, paramount everyday reality, and immersed in the flow of time which, just as Bergson's durée, is too complex to our analyzing consciousness and hence inaccessible for our direct reflection. The question of our cognitive access to that flow is, as a matter of fact, not fully described in Schutz's project, and the further inquiry into this matter remains maybe the biggest challenge of this type of reflection. ${ }^{35}$ The basic, fundamental time flow, in which the meaning of social action is actually and permanently being constituted, is accessible to Schutz only metaphorically - particularly important in this regard are his writings about the phenomenology of music, echoing Husserl's analyses from his lectures on the inner time consciousness ${ }^{36}$, because, as Schutz puts it, "music is a meaningful context which

${ }^{31}$ R. Venturini, ,Time, intersubjectivity, and musical relationship in Alfred Schutz”, Società Mutamento Politica, vol. 6, nr 12 (2015) 165-201. 165.

32 A Schutz, The phenomenology of the social world, op. cit., p. 12; cf. R. Venturini, op. cit., p. 165; Luigi Muzzetto, op. cit., p. 7; Thomas Luckmann, “Geschichtlichkeit der Lebenswelt?", Filozofsky Vestnik 2 (1991), p. 23-37, 26-27 (cf. the same text in: Thomas Luckmann, Lebenswelt, Identität und Gesellschaft, Universitätsverlag Konstanz, Konstanz 2007, p. 193-205).

33 A. Schütz, Der sinnhafte Aufbau der sozialen Welt, op. cit., p. 8; J. Šubrt, „The Problem of Time from the Perspective of the Social Sciences“, Czech Sociological Review IX-2 (2001), p. 211-224. 219.

34 Th. Blin, Requiem pour une phénoménologie, op. cit., p. 68.

35 There are even authors - like Luigi Muzzeto, op. cit., p. 15 - attributing unconscious character to the ground of because-motives in Schutz, notwithstanding the fact that Schutz declares e. g. that speaking of unconscious experiences is contradictory, since "in our view experience implies consciousness" (A. Schutz, The Phenomenology of the Social World, op. cit., p. 63; Der sinnhafte Aufbau (1960), op. cit., p. 63). But Schutz's further considerations from the same fragment prove that we can speak about some form of "unconsciousness" of experiences and action (Handeln), and that the whole question is deeply paradoxical, as is the problem of unconsciousness in the philosophy of consciousness in general.

36 A. Schutz, Frammenti di Fenomenologia della musica, Guerini e Associati, Milano 1996 [1964]; cf. A.G. Goettlich, ,Music, Meaning, and Sociality: From the Standpoint of a Social Phenomenologist",in: M. Barber, J. Dreher (ed.), The Inerrelation of Phenomenology, Social Sciences and the Arts, Springer, Dordrecht 2014, 243-258; R. Venturini, op. cit., p. 172 f.; B. Jabłońska, Teoretyczne źródta socjologii muzyki w świetle klasycznej myśli H. Spencera, G. Simmla, M. Webera oraz 
is not bound to a conceptual scheme"; "yet this meaningful context can be communicated"37.

What is, however, very well analized and described in Schutz's theory, is the reflexive, conscious side of the process of social constitution of meaning, related to attributing explicit meaning to social action. Accessible to consciousness, and actively participating in the constitution of social meaning, are our projects of actions, present to us not as genuine facts or events, but as projects of actions accomplished in phantasy and given in the temporal form of the future perfect tense (modo futuri exacti) ${ }^{38}$. These projects of future actions are, however, genuine intentional acts, shaping not only our present and future actions, but also our vision of the past. The very flow of time, the process of the constitution of meaning, on the other hand, is accessible to us not as present, but as already past acts, as completed actions, conceived in the form of the past tense (modo praeterito).

Paradoxical in this description of the conscious side of the temporal constitution of meaning is the awkward fact that we never actually consciously deal with the present, nor even with the future, but always with the past, be it imagined or remembered. The whole issue of remembering, recollecting, reminding, reminiscing and recognizing the past, as analyzed in the phenomenological reflection ${ }^{39}$, seems to be of paramount importance for further understanding of the constitution of meaning and self-evidence of the socially given world.

\section{CONSLUSION: HUSSERL AND SCHUTZ ON THE NATURE OF PHENOMENOLOGICAL REDUCTION}

In the postscript to his Formal and Transcendental Logic, published in 1930 and read with interest and attention by Schutz, Edmund Husserl poignantly explained the misunderstanding concerning his alleged idealism and the nature of his transcendental phenomenology in Ideas $I$, stressing fundamental unity between the transcendental and the mundane side of his philosophy. As he states there, "people didn't understand the principal new thing of the 'phenomenological reduction' and therefore the ascension from the mundane subjectivity (human being) to the transcendental subjectivity"40. Further he added: "That the world exists, is totally doubtless. A quite different thing is to understand this doubtlessness carrying this life and positive science and to clarify its ground. (...) The transcendental intersub-

A. Schütza [The theoretical foundations of the sociology of music in the light of the classics: Spencer, Simmel, Weber and Schütz], Muzyka: Kwartalnik Instytutu Sztuki Polskiej Akademii Nauk 58-1 (2013), s. 3-21.

${ }^{37}$ R. Venturini, op. cit., p. 172.

38 A. Schutz, The phenomenology of the social world, op. cit., p. 82f.; R. Venturini, op. cit., p. 166.

${ }^{39}$ For the classical analysis in this domain, see E.S. Casey, Remembering. A Phenomenological Study, Indiana University Press, Bloomington, IN 2000.

${ }^{40}$ E. Husserl, Ideen zu einer reinen Phänomenologie und phänomenologischen Philosophie. Drittes Buch: Die Phänomenologie und die Fundamente der Wissenschaft (Husserliana V), ed. M. Biemel, M. Nijhoff, D. Haag 1971, p. 140; quoted after: Shinji Hamazau, „Identity and Alterity - Schutz and Husserl on Phenomenology of Intersubjectivity“, in: K. Lau, C. Cheung, T. Kwan (ed.), Identity and Alterity. Phenomenology and Cultural Traditions, Königshausen \& Naumann, Würzburg 2010, p. 99-112. 102. 
jectivity is therefore that in which real world is constituted as objective, as being for everyone" ${ }^{\text {"4l }}$. This integral unity of the phenomenology of the transcendental ego and the phenomenology of the lifeworld, and the obvious realism of the Husserlian epoche resulting thereof was later defended by Alfred Schutz in a remarkable commentary to his master's philosophy, "Husserl on the Problem of Transcendental Intersubjectivity", presented at Husserl-Colloquium in Royaumont in 1957 and discussed there with, among others, Eugen Fink and Roman Ingarden ${ }^{42}$. Schutz defended there basic positions concerning the mundane, realistic character of transcendental reduction, and criticizing at the same time certain interpretational changes that have occurred later in Husserl's writings: He wrote that an essential difficulty consists in "a transformation of sense which the concept of constitution has undergone in the course of the development of phenomenology"43. "At the beginning of phenomenology, constitution meant clarification of the sense-structure of conscious life, inquiry into sediments in respect of their history, tracing back all cogitata to intentional operations of on-going conscious life. (...) But unobtrusively, and almost unaware, it seems to me, the idea of constitution has changed from an explication of the sense of being, into the foundation of the structure of being; it has changed from explication into creation" 44 . "Husserl's failure [to account for the constitution of transcendental intersubjectivity]", explains Schutz further in the same text, "is due to his attempt to interpret the ontological status of social reality within the life-world as the constituted product of the transcendental subject, rather than explicating its transcendental sense in terms of operations of consciousness of the transcendental subject". ${ }^{45}$ Alfred Schutz, faithful to Husserl's original project of phenomenology, renounced that temptation of such acute ontologization of phenomenological reduction, suggesting solipsism of the transcendental ego and idealism, and pursued his analysis as "an explication of the sense of being", understood, however, not as a vague Daseinsanalytik, but as a legitimate field of empirical studies, thus acquiring a high status of one of the founding fathers of contemporary sociology. The consequences of this theoretical manoeuvre are yet to be studied and analyzed, making possible a rediscovery of phenomenology's project.

\section{REFERENCES}

1. Aspers P., "The Second Road to Phenomenological Sociology", Society 47-3 (2010), p. 214-219.

2. Bakker J.I. (Hans), The Life World, Grief and Individual Uniqueness: Social 'Definition' in Dilthey, Windelband, Rickert, Weber, Simmel and Schutz, Sociologische Gids 42-3 (1995), p. 187-212.

3. Barber M., "If only to be heard: value-freedom and ethics in Alfred Schutz's economic and political writings", in: Martin Endress, George Psathas, Hisashi Nasu (eds.), Explorations of the Life-World. Continuing Dialogues with Alfred Schutz, Springer, Dordrecht 2005, p. 173-202.

\footnotetext{
${ }^{41}$ Ibidem, p. 153; S. Hamazau, op. cit., p. 102.

42 A. Schütz, Gesammelte Aufsätze, M. Nijhoff, Den Haag 1971, p. 90 f.; quoted after: S. Hamazau, op. cit., p. 104.

43 A. Schütz, Gesammelte Aufsätze, op. cit., p. 117; S. Hamazau, op. cit., p. 104.

44 A. Schütz, Gesammelte Aufsätze, op. cit., p. 117; S. Hamazau, op. cit., p. 104-105.

45 A. Schütz, Gesammelte Aufsätze, op. cit., p. 122; S. Hamazau, op. cit., p. 104.
} 
4. Barber M., „Alfred Schutz”, in: E.N. Zalta, U. Nodelman, C. Allen, R.L. Anderson (ed.), Stanford Encyclopedia of Philosophy, Stanford University, Stanford, CA 2016, https://plato.stanford.edu/entries/schutz/.

5. Blin T., Requiem pour une phénoménologie. Sur Alfred Schütz, Merleau-Ponty et quelques autres, Editions du Félin, Paris 2010.

6. Casey E.S., Remembering. A Phenomenological Study, Indiana University Press, Bloomington, IN 2000.

7. Comte A., Système de politique positive. Tome deuxième contenant la statique sociale ou le traité abstrait de l'ordre humain, Otto Zeller, Osnabrück 1967 [1852].

8. Dreher J., "Einleitung", in: T. Luckmann, Lebenswelt, Identität und Gesellschaft, Universitätsverlag Konstanz, Konstanz 2007, p. 7-23.

9. Endress M., „Einleitung der Herausgeber“, in: A. Schutz, Der sinnhafte Aufbau der sozialen Welt, UVK, Konstanz 2004, p. 7-66.

10. Gareman R.A., The dual vision. Alfred Schütz and the myth of phenomenological social science, Routledge, London-New York 2014 [1977].

11. Gillian R., Hegel: Contra sociology, The Athlone Press, London 1995.

12. Goettlich A.G., „Music, Meaning, and Sociality: From the Standpoint of a Social Phenomenologist",in: M. Barber, J. Dreher (ed.), The Inerrelation of Phenomenology, Social Sciences and the Arts, Springer, Dordrecht 2014, 243-258.

13. Hamazau S.,, „Identity and Alterity - Schutz and Husserl on Phenomenology of Intersubjectivity“, in: K. Lau, C. Cheung, T. Kwan (ed.), Identity and Alterity. Phenomenology and Cultural Traditions, Königshausen \& Naumann, Würzburg 2010, p. 99-112.

14. Helle H.J., Theorie der symbolischen Interaktion. Ein Beitrag zum verstehenden Ansatz in Soziologie und Sozialpsychologie, Westdeutscher Verlag, Wiesbaden 2001.

15. Husserl E., Ideen zu einer reinen Phänomenologie und phänomenologischen Philosophie. Drittes Buch: Die Phänomenologie und die Fundamente der Wissenschaft (Husserliana V), ed. Marly Biemel, M. Nijhoff, Den Haag 1971.

16. Husserl E., Logical investigations, transl. J.N. Findlay, Routledge, London-New York 2008 [1900].

17. Jabłońska B., Teoretyczne źródta socjologii muzyki w świetle klasycznej myśli H. Spencera, G. Simmla, M. Webera oraz A. Schütza [The theoretical foundations of the sociology of music in the light of the classics : Spencer, Simmel, Weber and Schütz], Muzyka: Kwartalnik Instytutu Sztuki Polskiej Akademii Nauk 58-1 (2013), s. 3-21.

18. Krasicki J., „Russian Values and America”, in: M.C. Flamm, J. Lachs, K.P. Skowroński (ed.), American and European Values. Contemporary Philosophical Perspectives, Cambridge Scholars Publishing, Newcastle 2008, p. 26-35.

19. Kusch M., Psychologism. A Case Study in the Sociology of Philosophical Knowledge, Routledge, London-New York 1995.

20. Luckmann T., „Geschichtlichkeit der Lebenswelt?“, Filozofski Vestnik 2 (1991), p. 24-25 (also in: T. Luckmann, Lebenswelt, Identität und Gesellschaft, Universitätsverlag Konstanz, Konstanz 2007, p. 193-205).

21. Marquis N., "Blin Thierry, Requiem pour une phénoménologie. Sur Alfred Schütz, Merleau-Ponty et quelques autres", Recherches sociologiques et anthropologiques, 41-2 (2010), p. 142-145.

22. Mulligan K., Smith B., "Husserl's Logical Investigations", Grazer Philosophische Studien 27(1986), p. 199-207. 
23. Muzzetto L., „Time and Meaning in Alfred Schütz”, Time and Society 15 (2006), p. 5-31.

24. Nenon T., „Max Weber“, in: L. Embree et al. (eds.), Encyclopedia of Phenomenology, Kluwer, Dordrecht-Boston-London 1997, p. 729-732.

25. Salice A., Schmid H.B., "Social Reality - The Phenomenological Approach", in: A. Salice, H.B. Schmid (ed.), The Phenomenological Approach to Social Reality. History, Concepts, Problems, Springer, New York-Berlin-Heidelberg 2016, p. 1-16.

26. Scheuch E.K., „Vorwort“, in: H.J. Helle, Theorie der symbolischen Interaktion, op. cit., p. 3.

27. Schutz, Alfred, Frammenti di Fenomenologia della musica, Guerini e Associati, Milano 1996 [1964].

28. Schütz A., Gesammelte Aufsätze, M. Nijhoff, Den Haag 1971.

29. Schutz A., The Phenomenology of Social World, transl. and ed. by George Walsh and Frederick Lehnert, Northwestern University Press, Evanston, Ill. 1972 [1967]; original edition: Alfred Schütz, Der sinnhafte Aufbau der sozialen Welt. Eine Einleitung in die verstehende Soziologie, Springer Verlag, Wien 1960 [1932].

30. Srubar I., Kosmion. Die Genese der pragmatischen Lebensweltstheorie von Alfred Schütz und ihr anthropologischer Hintergrund, Suhrkamp, Frankfurt am Main 1988.

31. Uebel, T., "Vienna Circle", in: The Stanford Encyclopedia of Philosophy (2016), https://plato.stanford.edu/entries/vienna-circle/

32. Venturini R., ,Time, intersubjectivity, and musical relationship in Alfred Schutz”, Società Mutamento Politica, vol. 6, nr 12 (2015), p. 165-201.

33. Walsh G., „Introduction”, in: A. Schutz, The Phenomenology of the Social World, op.cit., p. XV-XXX.

34. Wundt W., Kleine Schriften, vol. 1, Wilhelm Engelmann Verlag, Leipzig 1910.

\section{CZAS I SENS. POJECIE INTERSUBIEKTYWNOŚCI ALFREDA SCHUTZA I JEGO ISTOTNOŚĆ EPISTEMOLOGICZNA}

Dlaczego dziedzictwo Alfreda Schutza w tak znacznej mierze wpłynęło na teorię społeczną, pozostając zarazem stosunkowo mało znane w świecie filozofii, a zwłaszcza fenomenologii? Artykuł próbuje wykazać jego znaczenie dla tradycji fenomenologicznej, wskazując na istotność koncepcji Schutza dla takich problemów filozoficznych, jak rozumienie redukcji fenomenologicznej, oczywistość, zarzut psychologizmu, konstytuowanie się sensu i opozycja pomiędzy realizmem i idealizmem $\mathrm{w}$ fenomenologii. Podkreślając znaczenie, jakie myśli Schutza przypisywał Edmund Husserl, wychodzi on od historycznego tła refleksji Schutza (austriacka szkoła prawa i ekonomii, neokantyzm szkoły marburskiej i badeńskiej oraz jej wpływ na Maxa Webera, polemika Husserla z psychologizmem) by wykazać, na przykładzie „Fenomenologii świata społecznego”, jak Schutz unika pułapki solipsystycznej, rozwiązując problem oczywistości za pomocą opisu przedrefleksyjnego i refleksyjnego aspektu czasowej struktury doświadczenia, wpisanej w proces społecznego konstytuowania się sensu.

Analiza rozpoczyna się od nakreślenia historycznego tła refleksji Schutza, przechodząc od inspiracji teoriami prawnymi i ekonomicznymi, poprzez zaangażowanie w dyskusję o uzasadnieniu nauk humanistycznych i stanowisko, jakie zajął w niej Max Weber, stanowiące dla Schutza punkt wyjscia, do odniesienia Schutza do podstawowych kwestii fenomenologii, 
streszczających się w zarzucie psychologizmu. Po tym wstępie refleksja Schutza okazuje się być rekonstrukcją oczywistości poznawczej pojętej jako proces, realizującej się we współistnieniu różnych strumieni świadomości, konkurującą poniekąd z Byciem i czasem Heideggera.

Słowa kluczowe: fenomenologia, neokantyzm, teoria społeczna, Alfred Schutz, Edmund Husserl, Max Weber.

DOI: $10.7862 /$ rz.2018.hss.21

Przestano do redakcji: styczeń $2018 \mathrm{r}$.

Przyjęto do druku: czerwiec 2018 r. 